\title{
Monochromosomal Hybrids and Chromosome Transfer: A Functional Approach for Gene Identification
}

\author{
RAJ P. KANDPAL ${ }^{1 *}$, ARBANS K. SANDHU ${ }^{2}$, GURPREET KAUR ${ }^{2}$, \\ GURSURINDER P. KAUR ${ }^{2}$ and RAGHBIR S. ATHWAL ${ }^{2}$ \\ ${ }^{1}$ Department of Basic Medical Sciences, Western University of Health Sciences, Pomona, CA, U.S.A.; \\ ${ }^{2} \mathrm{Fels}$ Institute for Cancer Research and Molecular Biology, \\ Temple University School of Medicine, Philadelphia, PA, U.S.A.
}

\begin{abstract}
Functional complementation of cellular defects has been a valuable approach for localizing causative genes to specific chromosomes. The complementation strategy was followed by positional cloning and characterization of genes for their biological relevance. We herein describe strategies used for the construction of monochromosomal hybrids and their applications for cloning and characterization of genes related to cell growth, cell senescence and DNA repair. We have cloned RNaseT2, GluR6 (glutamate ionotropic receptor kainate type subunit 2-GRIK2) and protein tyrosine phosphatase, receptor type $K$ (PTPRK) genes using these strategies.
\end{abstract}

The sequencing of the human genome has been an important milestone in modern biology $(1,2)$. This process involved characterization of clones with insert sizes ranging from a few thousand bases to a million bases in plasmid, bacteriophage, phagemid, cosmid, bacterial artificial chromosome and yeast artificial chromosome vectors (3-8). These cloned DNA segments, spanning across specific regions of human chromosomes, were subsequently sequenced and assembled together to generate contiguous

This article is freely accessible online.

Correspondence to: Dr. Raghbir S. Athwal, Fels Institute for Cancer Research, Temple University School of Medicine, Philadelphia, PA 19140, U.S.A. E-mail: rathwal@temple.edu and Dr. Raj Kandpal, Department of Basic Medical Sciences, Western University of Health Sciences, 309 E. Second Street, Pomona, CA 91766, U.S.A. E-mail: rkandpal@westernu.edu

Key Words: Chromosome transfer, monochromosomal hybrids, functional cloning, cell senescence, senescence associated $\beta$-galactosidase, glutamate ionotropic receptor kainate type subunit 2, GRIK-2, GluR6, protein tyrosine phosphatase, receptor type K (PTPRK), review. stretches of genomic sequences. This entire process involved contributions from numerous laboratories either individually or as part of large consortia. A variety of methods were used to generate the starting DNA for creating genomic libraries. One such method for library preparation involved purification of individual human chromosomes based on their sizes (9-12). The purification of individual chromosomes was facilitated by using monochromosomal/ somatic cell hybrids (13-15).

In light of the utility of somatic cell hybrids in the pregenomic era, we present a historical perspective of chromosome transfer strategies, and construction and applications of monochromosomal hybrids for identifying a variety of important genes. Despite the availability of the complete human genome sequence, monochromosomal cell hybrids remain an important resource for investigating the functional significance of various genomic regions. Here we have emphasized the production and the value of monochromosomal hybrids for cloning of genes responsible for specific cellular functions.

\section{Transfer of Chromosomes into Recipient Cells}

The success in creating hybrid cells paved the way to develop experimental strategies for investigating the expression and functional significance of human genes. It was known in 1962 that mammalian cells can fuse together to form polynuclear cells (16), and hybrid cells had been derived from mouse and man by 1965 (17). It is noteworthy that only a few human chromosomes were retained in the hybrid cells when human and mouse cells were fused together (18). These observations indicated the potential utility of hybrid cells for mapping genes onto various human chromosomes. The presence of multiple human chromosomes in a unique combination in clones of segregating mouse-human hybrid cells facilitated mapping of genes to specific human chromosomes (19). 


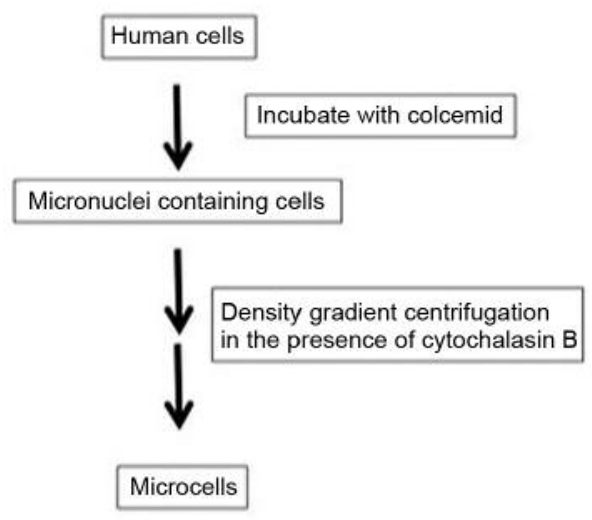

Figure 1. Schematic for isolating microcells. The human cells were transfected with cloned XGPRT gene, and subsequently cultured in a selection medium containing mycophenolic acid and xanthine. Further treatment of these cultured human cells with colcemid leads to micronuclei formation, which are released as microcells in the presence of cytochalasin $B$. The microcells are separated by density-gradient centrifugation.

Based on the packaging of eukaryotic genetic material as a well-defined compact chromatin structure in metaphase (20), it was predicted that chromosomes can be transferred from donor cells to recipient cells. McBride and Ozer took advantage of such organized packaging of chromatin and showed the transfer of functional genes using metaphase chromosomes from Chinese hamster fibroblasts into mouse A9 cells (21). The mutant status of HPRT gene in A9 cells allowed the selection of clones for the presence of specific donor chromosome (22). These experiments demonstrated unambiguous transfer and stable expression of donor HPRT gene in the recipient cells, and set the basis for using chromosome transfer as a feasible tool for gene identification (23). It warrants mentioning that this was the conclusive demonstration of the transfer and expression of functional genes in mammalian cells.

\section{Chromosome Transfer in Mammalian Cells}

The initial success of chromosome transfer experiments was followed by the transfer of a variety of human and rodent genes into mutant recipient cell lines $(24,25)$. The frequency of transfer, however, was very low in the presence of poly-lysine buffer used by McBride and Ozer (21). The limitations posed by low frequency transfer were subsequently addressed by applying specific modifications to the chromosome transfer methodology. Spandidos and colleagues (26) were able to marginally improve the transfer frequency using a buffer system containing calcium phosphate. Miller and Ruddle (27) employed a modified protocol that included treatment with $10 \%$ dimethyl sulfoxide $4.25 \mathrm{~h}$ after mixing the metaphase chromosomes with the recipient cells.

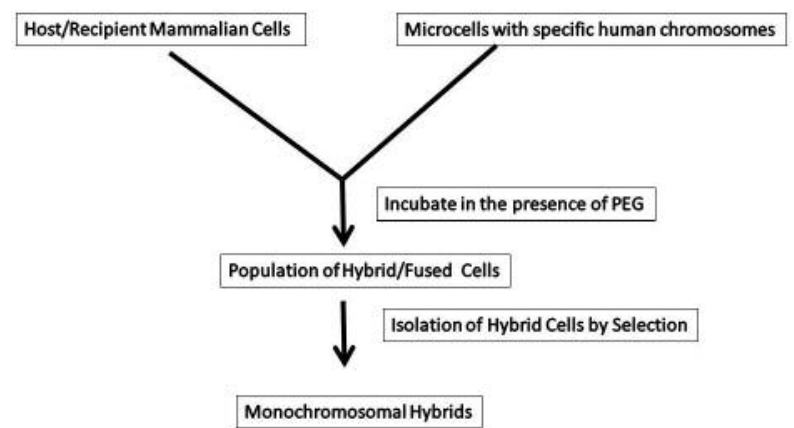

Figure 2. Strategy for fusion of microcells with recipient mammalian cells. The microcells were fused with the recipient mouse A9 cells in the presence of polyethylene glycol, and monochromosomal hybrids were isolated by culturing the fused cells in the selection medium containing either $G 418$ or a mixture of mycophenolic acid and xanthine.

This modification significantly improved transfer frequency as well as the size of the transferred chromosomal fragments. Although the transferred chromosomal fragments were readily detectable in the recipient cells (27), the fate of the transferred DNA was not clear. Using a sequential transfer strategy, Athwal and McBride (28) first demonstrated that the transferred genetic material integrates at random into the recipient cell chromosomes. The random integration of human thymidine kinase (TK) and adenine phosphoribosyl transferase (APRT) genes provided a method for integration of a selectable marker in recipient cells (29-31). Subsequently, the introduction of cloned selectable prokaryotic genes such as xanthine guanine phosphoribosyltransferase (XGPRT) and neomycin resistance gene into mammalian cells provided a highly efficient method for chromosome tagging (32).

\section{Monochromosomal Hybrids}

The standardization of protocols for high efficiency chromosome transfer set the stage to accomplish gene mapping and functional complementation of cellular defects. Initial strategies were aimed at establishing a panel of somatic cell hybrids by somatic cell hybridization and random elimination of a majority of human chromosomes from fused nuclei of human and rodent hybrids (33-35). This hybridization technique was subsequently improved for establishing monochromosomal hybrids by employing fusion of micronuclei (36-38). Micronuclei arise due to partitioning of chromosomes during prolonged arrest of cells in mitosis. These micronuclei that contain a single or few chromosomes can be subsequently purified by disruption of microfilaments followed by centrifugation (38). The isolated micronuclei surrounded by plasma membrane are termed "microcells". A flow chart of this strategy is shown in Figure 1. 

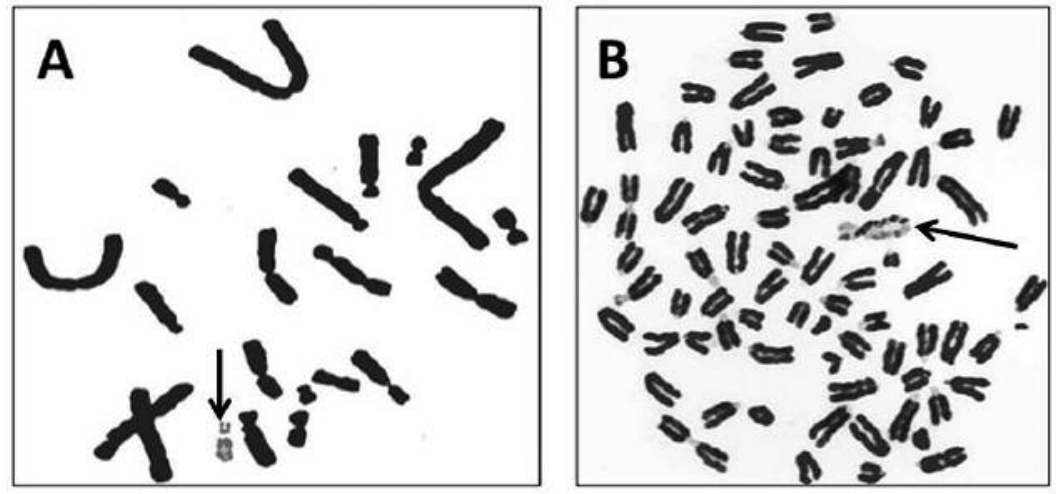

Figure 3. Identification of transferred human chromosome by Giemsa 11 staining. Panels A and B show the presence of a single human chromosome (lightly stained) in Chinese hamster background (panel A) and mouse background (panel B). The arrow shows lightly stained human chromosome.

The microcells are size-fractionated and subsequently fused with rodent cells in the presence of polyethylene glycol (PEG) for delivering the human chromosomes into the recipient cells. The advantage of the microcell-based chromosome transfer is that it does not depend on spontaneous elimination of transferred chromosomes for obtaining monochromosomal hybrids (38). The fusion product is cultured in a selection medium to facilitate the growth of cells containing the chromosome tagged with a marker. This protocol, as schematized in Figure 2, shows a single step production of monochromosomal hybrids.

\section{Characterization of Monochromosomal Hybrids}

The monochromosomal hybrids were characterized by using several different methods to ascertain that each hybrid contains a single specific chromosome. These methods included characteristic karyotypes and banding patterns obtained by Giemsa 11 and Hoechst staining (39). An illustration of Geimsa staining in Figure 3 shows metaphase chromosomes of a hybrid that contained human chromosome 5 in the rodent background.

The initial identity of a specific chromosome present in a monochromosomal hybrid was determined by zymographic analysis of cell lysates, which involves biochemical detection of isozymes encoded by specific human chromosomes. The presence of single human chromosome(s) in the hybrid cells was further confirmed by fluorescence in situ hybridization (FISH) and probing Southern blots of the hybrid cell DNA with human DNA. The existence of human chromosome specific DNA in the hybrid cell is evident from the signal shown in Figure 4. The chromosome transfer method described here has yielded a panel of hybrid cell lines each containing a single different human chromosome and thus representing the entire human genome. Table I presents the details of 22 cell lines characterized for the presence of each of the 21 autosomes and the $\mathrm{X}$ chromosome.

The human chromosomes in the hybrid cell lines shown in Table I exist in the background of mouse A9 cells. A similar hybrid panel has also been produced in Chinese hamster CHTG49 cells. The human chromosomes present in these monochromosomal hybrids are tagged with a selectable marker GPT (guanine phosphoribosyltransferase) (41). Similarly, neomycin resistance gene (neo) was integrated in chromosomes 10 and 20 as a selectable marker. A large number of hybrid cells were characterized, and the 20 cell lines shown in the table contain a single GPT-tagged chromosome. RA4A7 and RA20A hybrid cell lines harbor neomycin-tagged chromosomes. It warrants mention that GPT and neo markers were important for selecting the somatic cell hybrids that retained specific human chromosomes.

As previously described, these hybrids were characterized by Giemsa banding (Figure 3), FISH (Figure 4) and PCR karyotyping (41). Southern hybridization with human DNA prepared by Alu-PCR of a hybrid cell DNA was used to exclude the presence of a specific chromosome in other hybrid cells. Figure 5 demonstrates the characteristic hybridization of hybrid cells containing chromosome 2 . These techniques confirmed the presence and identities of individual human chromosomes in monochromosomal hybrids.

\section{Applications of Monochromosomal Cell Hybrids}

Somatic cell hybrids have been useful in the pre- as well as post-genomic era. These hybrids have been used for gene mapping and identification of senescence genes, growth/tumor suppressing genes and DNA repair genes. The following sections highlight representative examples of such applications of monochromosomal hybrids. 


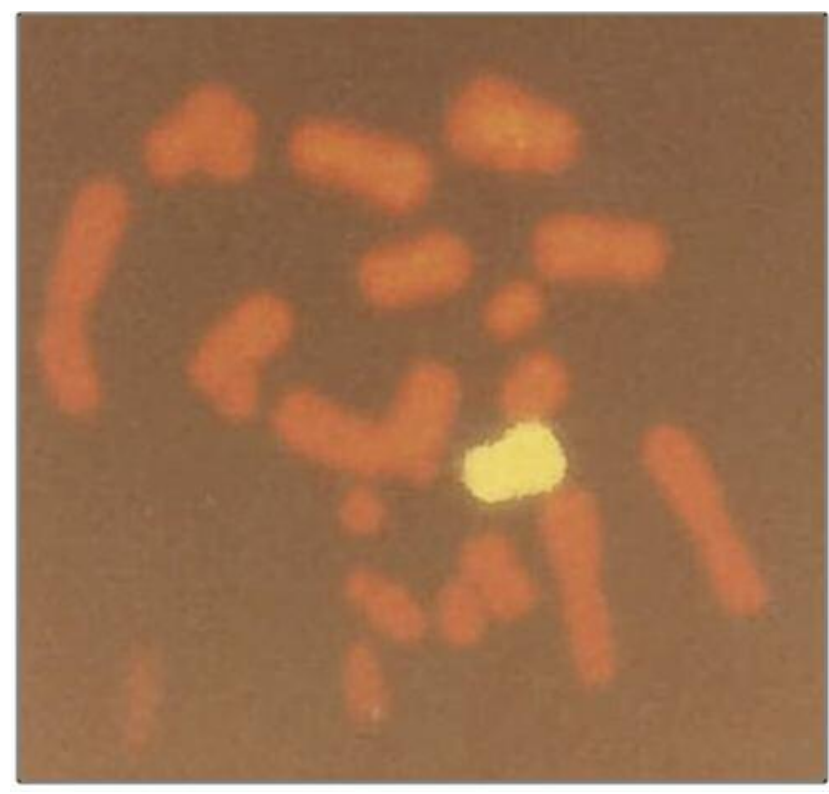

Figure 4. Fluorescence in situ hybridization. Metaphase chromosomes were hybridized with fluorochrome-tagged total human DNA and visualized under a fluorescence microscope. The bright yellow signal indicates the transferred human chromosome among Chinese hamster metaphase chromosomes.

\section{Gene Mapping}

Monochromosomal hybrids provided an extremely convenient methodology for mapping of any unique DNA or cDNA fragment to a specific chromosome (42-46). The map positions of specific genes were further refined by using subchromosomal hybrids $(38,42)$. Furthermore, monochromosomal hybrids were used to transfer known chromosomes/ chromosomal regions to recipient cells to identify genes that complement mutant phenotypes related to cell growth and DNA repair. This proved to be a highly productive approach to characterize genes involved in cell senescence, tumor suppression and DNA repair, as described below.

\section{Senescence Genes}

The normal cells have a finite life span, which culminates into cessation of proliferation and acquisition of characteristic morphological changes. In contrast, cells cultured from many tumors can proliferate indefinitely. It was reasoned that these immortal cells arise by mutations in certain genes that under normal circumstances are responsible for senescence. If indeed mutant genes were to be present in tumor cells then complementation of these defective genes by chromosome transfer should restore the normal phenotype of the cell. In the absence of any knowledge about the identity of these genes, transfer of specific chromosomes using monochromosomal hybrids was a logical and an ideal choice to identify the
Table I. A panel of somatic cell hybrid cell lines with specific human chromosome(s) in a rodent background*.

\begin{tabular}{lccc}
\hline Cell Line & Chromosome(s) & Host & Marker \\
\hline RA1A & 1 & A9 & GPT \\
RA2-1 & 2 & A9 & GPT \\
RA3A & 3 & A9 & GPT \\
RA4A7 & $4 \& 7$ & A9 & GPT \\
RA5A & 5 & A9 & GPT \\
RA6A & 6 & A9 & GPT \\
RA7A & 7 & A9 & GPT \\
RA8A1 & 8 & A9 & GPT \\
RA9 & 9 & A9 & GPT \\
RA10 & 10 & A9 & Neo \\
RA11 & 11 & A9 & GPT \\
RA12A & 12 & A9 & GPT \\
RA13A & 13 & A9 & GPT \\
RA14A & 14 & A9 & GPT \\
RA15A & 15 & A9 & GPT \\
RA16A & 16 & A9 & GPT \\
RA17A & 17 & A9 & GPT \\
RA18A & $18 \& 5$ & A9 & GPT \\
RA19A & 19 & A9 & GPT \\
RA20A & 20 & A9 & Neo \\
RA21 & 21 & A9 & GPT \\
RAXA & X & A9 & GPT \\
\hline
\end{tabular}

* Similar monochromosomal hybrid cell lines are also available in Chinese hamster CHTG49 background.

complementing gene(s). In fact, chromosome transfer in immortal cells has led to restoration of senescence, and such chromosome transfer experiments have allowed identification of senescence loci on several different chromosomes. Chromosome transfer has been particularly useful for characterizing chromosomes 6 and 16 for their abilities to impart senescence to immortal cells (47). The confirmation of these observations has been obtained by restoring senescence of immortal cells upon introduction of a specific region of chromosome $6(48,49)$. These results are supported by observations indicating the loss of chromosome segments in SV40-transformed human fibroblasts (50). We have observed similar effects upon introduction of chromosome 16 into breast and ovarian tumor cells (51). Figure 6 shows senescent phenotype of immortal cells by the presence of senescence associated (SA) $\beta$-galactosidase activity in transformed cells containing a normal chromosome 16. Upon transfer of chromosome 16, the cells acquire characteristic enlarged morphology as shown in Figure 7.

It warrants mentioning that the region of chromosome 6 responsible for attributing senescence to transformed cells encodes RNaseT2 and GluR6 (52). We have shown that RNaseT2, contrary to other observations (53), by itself does not cause senescence, but modulates cell proliferation (52). Thus, GluR6 $(52,54)$ appears to be an attractive senescence 


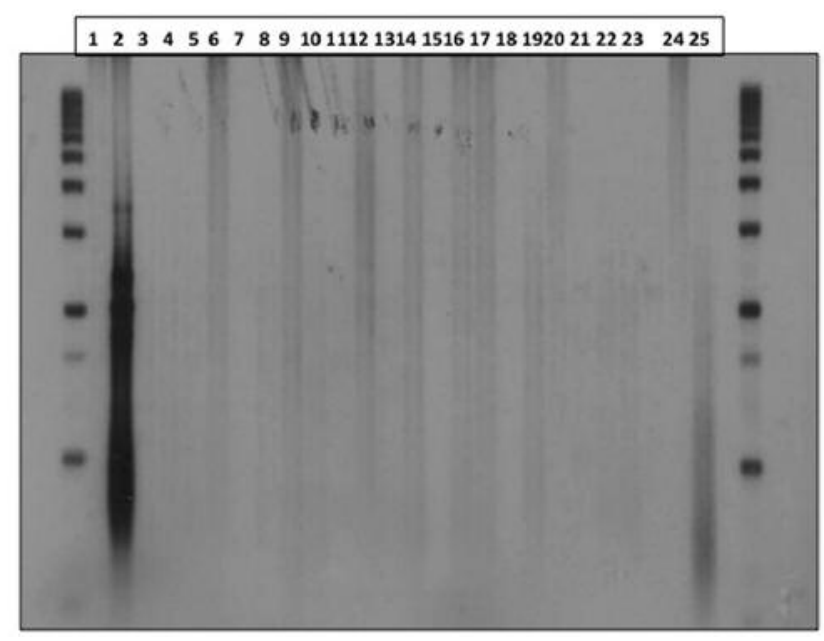

Figure 5. Southern blot analysis of DNA from monochromosomal hybrids. Genomic DNA isolated from 24 different somatic cell hybrids was digested with a restriction enzyme and the digested DNA separated by electrophoresis on an agarose gel. The separated DNA was transferred from the gel to a nylon membrane. The membrane blot was hybridized to a mixture of $32 \mathrm{P}$ labeled chromosome 2 specific human DNA. The blot was washed and then exposed an X-ray film. Intense signal is visible in the lane containing the DNA isolated from the chromosome 2 hybrid. Lane 25 represents control human DNA.

gene for further consideration. The confirmation of GluR6 involvement will be the first proof-of-principle demonstration of chromosome transfer strategy for the identification of senescence genes, which will have significant implications for investigating aging process. In addition to GluR6, we have also identified PTPRK as a putative cell senescence gene on chromosome 6 (unpublished observation).

\section{Tumor/Growth Suppressor Genes}

Aberrant regulation of cell growth and proliferation is implicated in the initiation, development and metastasis of human cancers. Growth suppression is an important arm of regulatory network for controlling cell proliferation. As previously discussed, chromosome transfer remains a valuable strategy for functional identification and positional cloning of genes involved in human cancers. The identification and cloning of RNAseT2 (52) represents an illustrative example of the application of chromosome transfer strategy. The modulation of cancer cell phenotypes following chromosome transfer (55-58) indicates the presence of responsible genes on specific chromosomes. Based on these observations, we believe that chromosome transfer is a productive approach for identifying genes involved in growth/tumor suppression.

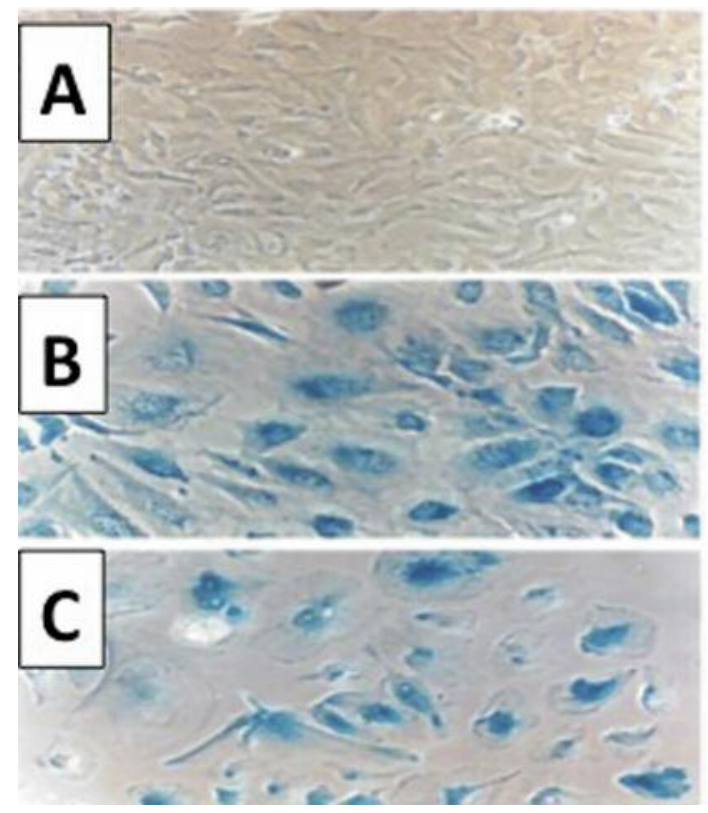

Figure 6. Senescence associated (SA) $\beta$-galactosidase expression in senescent human breast cancer cells (MCF7) after transfer of a normal chromosome 16. Chromosome 16 was transferred to human cancer cells by microcell-mediated procedure. Panel A shows native cancer cells, and panels $B$ and $C$ show $S A \beta$-galactosidase expressing senescent cells after the transfer of chromosome 16.

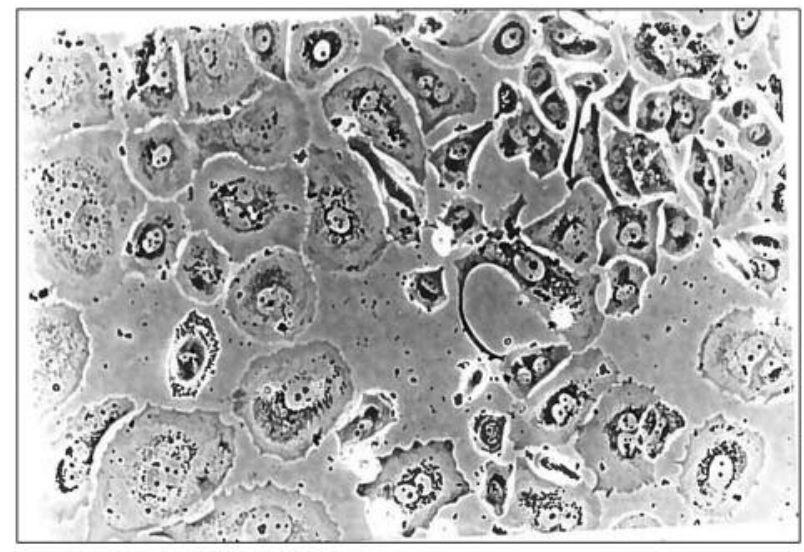

Figure 7. Enlarged morphology of senescent cells. The picture shows enlarged senescent cells after introduction of a normal human chromosome 16 into MCF7 cells.

\section{DNA Repair Genes}

Chromosome transfer strategy has also been successful for identifying DNA double strand break and excision repair genes. In particular, the complementation of genes defective in xeroderma pigmentosum (XP), an extensively investigated genetic defect, has been assigned to seven different 
complementation groups XP-A through XP-G. While the genes for XP complementation groups B, C, A, E, G, F and $\mathrm{D}$ are located on chromosomes 2, 3, 9, 11, 13, 16 and 19, respectively, the double strand break repair genes are assigned to chromosomes 2 and 8 . Functional complementation of these defects has been confirmed and some of these genes cloned by applying chromosome transfer technique (59-66).

\section{Monochromosomal Hybrids and Genotoxicity of Environmental Chemicals}

Monochromosomal hybrids have also been used for evaluating environmental chemicals for their ability to cause aneuploidy, chromosome breaks and gene mutations $(67,68)$. The experimental strategy involves exposure of monochromosomal hybrid cells to a test chemical followed by survival of cells in a selection medium. This selection process circumvents the need for tedious cytogenetic analysis for aneuploidy and chromosomal breaks $(67,68)$. This assay is amenable to automation by combining it with current devices available for cell and colony counting.

\section{Future Directions}

It is noteworthy that chromosome transfer technique is being improved for better efficiency and a variety of biomedical applications (69-74). In the post-genomic era, however, the focus of geneticists and molecular biologists is shifting from genes to proteins, an area termed "proteomics" (75). In addition to numerous other applications of monochromosomal hybrids, we propose a novel set of experiments aimed at isolating cell surface proteins encoded by different human chromosomes. Monochromosomal hybrids represent the fractionation of human genomic components i.e. individual human chromosomes present in rodent background. The proteins expressed in each hybrid will represent a mixture of mouse and human proteins encoded by a specific human chromosome. Cell surface proteins from hybrid cells can be used for raising antibodies that will subsequently be fractionated to isolate human specific antibodies. These proteins can then be sequenced by mass spectrometry, and the cell surface proteins corresponding to individual chromosomes can be exploited for diagnostic and therapeutic purposes against a variety of human diseases. This strategy can also be modified for isolating, characterizing and discovering miRNAs as well as long noncoding RNAs corresponding to individual human chromosomes. We recognize that it is a challenging task, but once accomplished it will be extremely useful.

In our opinion, chromosome transfer strategy has enormous promise for identifying tumor suppressor genes, and deciphering the involvement of senescent cells in modulating the phenotypes of malignant and premalignant cells. In tumor biology, the senescent cells may be akin to dormant cells, which influence the behavior of cancer cells. Senescence cells are implicated in enhancing inflammation associated with cancer progression (76), and these inflammatory responses may promote malignant transformation and suppress immune surveillance (77). These hypotheses can be tested by first converting tumor cells into senescent cells by introduction of specific chromosomes into tumor cells and then seeding these cells in a milieu of pre-malignant cells or malignant cells to observe the molecular, morphological and growth/proliferation changes in the target cells. Such experiments would also allow assessment of combinatorial effects of genes on cellular phenotypes.

Finally, cells engineered by chromosome transfer can lend themselves to investigating transcriptomic (mRNAs and miRNAs) and proteomic changes associated with cellular behaviors. With the advent of massively parallel sequencing strategies and rapid mass spectrometry, such experiments can yield a wealth of information on the molecular influence of intact normal chromosomes in genetically-defective cells. It should be noted that transfer of intact chromosomes is preferable than introduction of individual cDNA constructs. The transfer of intact chromosomes would allow assessing the effects of specific genes in the context of associated control regions of the genome. This would eliminate ectopic effects frequently arising due to random integration of cDNA constructs. Despite the availability of complete sequencing of the human genome and its coding complement, chromosome transfer strategy remains a valuable tool to validate the biological significance of coding as well as noncoding regions of the human genome.

\section{References}

1 Lander ES, Linton LM, Birren B, Nusbaum C, Zody MC, Baldwin J, Devon K, Dewar K, Doyle M, FitzHugh W, Funke R, Gage D, Harris K, Heaford A, Howland J, Kann L, Lehoczky J, LeVine R, McEwan P, McKernan K, Meldrim J, Mesirov JP, Miranda C, Morris W, Naylor J, Raymond C, Rosetti M, Santos R, Sheridan A, Sougnez C, Stange-Thomann Y, Stojanovic N, Subramanian A, Wyman D, Rogers J, Sulston J, Ainscough R, Beck S, Bentley D, Burton J, Clee C, Carter N, Coulson A, Deadman R, Deloukas P, Dunham A, Dunham I, Durbin R, French L, Grafham D, Gregory S, Hubbard T, Humphray S, Hunt A, Jones M, Lloyd C, McMurray A, Matthews L, Mercer S, Milne S, Mullikin JC, Mungall A, Plumb R, Ross M, Shownkeen R, Sims S, Waterston RH, Wilson RK, Hillier LW, McPherson JD, Marra MA, Mardis ER, Fulton LA, Chinwalla AT, Pepin KH, Gish WR, Chissoe SL, Wendl MC, Delehaunty KD, Miner TL, Delehaunty A, Kramer JB, Cook LL, Fulton RS, Johnson DL, Minx PJ, Clifton SW, Hawkins T, Branscomb E, Predki P, Richardson P, Wenning S, Slezak T, Doggett N, Cheng JF, Olsen A, Lucas S, Elkin C, Uberbacher E, Frazier M, Gibbs RA, Muzny DM, Scherer SE, Bouck JB, Sodergren EJ, Worley KC, Rives CM, Gorrell JH, Metzker ML, Naylor SL, Kucherlapati RS, Nelson DL, Weinstock GM, Sakaki Y, Fujiyama A, Hattori M, Yada T, Toyoda A, Itoh T, Kawagoe C, Watanabe H, Totoki Y, 
Taylor T, Weissenbach J, Heilig R, Saurin W, Artiguenave F, Brottier P, Bruls T, Pelletier E, Robert C, Wincker P, Smith DR, Doucette-Stamm L, Rubenfield M, Weinstock K, Lee HM, Dubois J, Rosenthal A, Platzer M, Nyakatura G, Taudien S, Rump A, Yang H, Yu J, Wang J, Huang G, Gu J, Hood L, Rowen L, Madan A, Qin S, Davis RW, Federspiel NA, Abola AP, Proctor MJ, Myers RM, Schmutz J, Dickson M, Grimwood J, Cox DR, Olson MV, Kaul R, Raymond C, Shimizu N, Kawasaki K, Minoshima S, Evans GA, Athanasiou M, Schultz R, Roe BA, Chen F, Pan H, Ramser J, Lehrach H, Reinhardt R, McCombie WR, de la Bastide M, Dedhia N, Blöcker H, Hornischer K, Nordsiek G, Agarwala R, Aravind L, Bailey JA, Bateman A, Batzoglou S, Birney E, Bork P, Brown DG, Burge CB, Cerutti L, Chen HC, Church D, Clamp M, Copley RR, Doerks T, Eddy SR, Eichler EE, Furey TS, Galagan J, Gilbert JG, Harmon C, Hayashizaki Y, Haussler D, Hermjakob H, Hokamp K, Jang W, Johnson LS, Jones TA, Kasif S, Kaspryzk A, Kennedy S, Kent WJ, Kitts P, Koonin EV, Korf I, Kulp D, Lancet D, Lowe TM, McLysaght A, Mikkelsen T, Moran JV, Mulder N, Pollara VJ, Ponting CP, Schuler G, Schultz J, Slater G, Smit AF, Stupka E, Szustakowki J, Thierry-Mieg D, ThierryMieg J, Wagner L, Wallis J, Wheeler R, Williams A, Wolf YI, Wolfe KH, Yang SP, Yeh RF, Collins F, Guyer MS, Peterson J, Felsenfeld A, Wetterstrand KA, Patrinos A, Morgan MJ, de Jong P, Catanese JJ, Osoegawa K, Shizuya H, Choi S, Chen YJ and Szustakowki J, International Human Genome Sequencing Consortium: Initial sequencing and analysis of the human genome. Nature 409: 860-921, 2001.

2 Venter JC, Adams MD, Myers EW, Li PW, Mural RJ, Sutton GG, Smith HO, Yandell M, Evans CA, Holt RA, Gocayne JD, Amanatides P, Ballew RM, Huson DH, Wortman JR, Zhang Q, Kodira CD, Zheng XH, Chen L, Skupski M, Subramanian G, Thomas PD, Zhang J, Gabor Miklos GL, Nelson C, Broder S, Clark AG, Nadeau J, McKusick VA, Zinder N, Levine AJ, Roberts RJ, Simon M, Slayman C, Hunkapiller M, Bolanos R, Delcher A, Dew I, Fasulo D, Flanigan M, Florea L, Halpern A, Hannenhalli S, Kravitz S, Levy S, Mobarry C, Reinert K, Remington K, AbuThreideh J, Beasley E, Biddick K, Bonazzi V, Brandon R, Cargill M, Chandramouliswaran I, Charlab R, Chaturvedi K, Deng Z, Di Francesco V, Dunn P, Eilbeck K, Evangelista C, Gabrielian AE, Gan W, Ge W, Gong F, Gu Z, Guan P, Heiman TJ, Higgins ME, Ji RR, Ke Z, Ketchum KA, Lai Z, Lei Y, Li Z, Li J, Liang Y, Lin X, Lu F, Merkulov GV, Milshina N, Moore HM, Naik AK, Narayan VA, Neelam B, Nusskern D, Rusch DB, Salzberg S, Shao W, Shue B, Sun J, Wang Z, Wang A, Wang X, Wang J, Wei M, Wides R, Xiao C, Yan C, Yao A, Ye J, Zhan M, Zhang W, Zhang H, Zhao Q, Zheng L, Zhong F, Zhong W, Zhu S, Zhao S, Gilbert D, Baumhueter S, Spier G, Carter C, Cravchik A, Woodage T, Ali F, An H, Awe A, Baldwin D, Baden H, Barnstead M, Barrow I, Beeson K, Busam D, Carver A, Center A, Cheng ML, Curry L, Danaher S, Davenport L, Desilets R, Dietz S, Dodson K, Doup L, Ferriera S, Garg N, Gluecksmann A, Hart B, Haynes J, Haynes C, Heiner C, Hladun S, Hostin D, Houck J, Howland T, Ibegwam C, Johnson J, Kalush F, Kline L, Koduru S, Love A, Mann F, May D, McCawley S, McIntosh T, McMullen I, Moy M, Moy L, Murphy B, Nelson K, Pfannkoch C, Pratts E, Puri V, Qureshi H, Reardon M, Rodriguez R, Rogers YH, Romblad D, Ruhfel B, Scott R, Sitter C, Smallwood M, Stewart E, Strong R, Suh E, Thomas R, Tint NN, Tse S, Vech C, Wang G, Wetter J, Williams S, Williams M, Windsor S, Winn-Deen E, Wolfe K, Zaveri J, Zaveri K, Abril JF, Guigó R, Campbell MJ, Sjolander KV, Karlak
B, Kejariwal A, Mi H, Lazareva B, Hatton T, Narechania A, Diemer K, Muruganujan A, Guo N, Sato S, Bafna V, Istrail S, Lippert R, Schwartz R, Walenz B, Yooseph S, Allen D, Basu A, Baxendale J, Blick L, Caminha M, Carnes-Stine J, Caulk P, Chiang YH, Coyne M, Dahlke C, Mays A, Dombroski M, Donnelly M, Ely D, Esparham S, Fosler C, Gire H, Glanowski S, Glasser K, Glodek A, Gorokhov M, Graham K, Gropman B, Harris M, Heil J, Henderson S, Hoover J, Jennings D, Jordan C, Jordan J, Kasha J, Kagan L, Kraft C, Levitsky A, Lewis M, Liu X, Lopez J, Ma D, Majoros W, McDaniel J, Murphy S, Newman M, Nguyen T, Nguyen N, Nodell M, Pan S, Peck J, Peterson M, Rowe W, Sanders R, Scott J, Simpson M, Smith T, Sprague A, Stockwell T, Turner R, Venter E, Wang M, Wen M, Wu D, Wu M, Xia A, Zandieh A and Zhu X: The sequence of the human genome. Science 291: 1304-1351, 2001.

3 Hershfield V, Boyer HW, Yanofsky C, Lovett MA and Helinski DR: Plasmid ColEl as a molecular vehicle for cloning and amplification of DNA. Proc Natl Acad Sci USA 71: 3455-3459, 1974.

4 Hines JC and Ray DS: Construction and characterization of new coliphage M13 cloning vectors. Gene 11: 207-218, 1980.

5 Collins J and Hohn B: Cosmids: a type of plasmid gene-cloning vector that is packageable in vitro in bacteriophage lambda heads. Proc Natl Acad Sci USA 75: 4242-4246, 1978.

6 Shizuya H, Birren B, Kim U J, Mancino V, Slepak T, Tachiiri,Y and Simon M: Cloning and stable maintenance of 300-kilobasepair fragments of human DNA in Escherichia coli using an Ffactor-based vector. Proc Natl Acad Sci USA 89: 8794-8797, 1992.

7 Burke DT, Carle, GF and Olson MV: Cloning of large segments of exogenous DNA into yeast by means of artificial chromosome vectors. Science 236: 806-812, 1987.

8 Tiemer D, Enquist, L and Leder, P: Improved derivative of a phage lambda EK2 vector for cloning recombinant DNA. Nature 263: 526-527, 1976.

9 Baron B, Metezeau P, Kiefer-Gachelin H and Goldberg ME: Construction and characterization of a DNA library from mouse chromosomes 19 purified by flow cytometry. Biol Cell 69: 1-8, 1990.

10 Davies KE, Young BD, Elles RG, Hill ME and Williamson R: Cloning of a representative genomic library of the human $\mathrm{X}$ chromosome after sorting by flow cytometry. Nature 293: 374376, 1981.

11 Krumlauf R, Jeanpierre $M$ and Young BD: Construction and characterization of genomic libraries from specific human chromosomes. Proc Natl Acad Sci USA 79: 2971-2975, 1982.

12 Weber BH, Stohr H, Siedlaczck I, Longmire JL, Deaven LL, Duncan AM and Riess O: Characterization of a cosmid library from flow-sorted chromosomes 11. Chromosome Res 2: 201207, 1994.

13 Arveiler B: Construction of chromosome-specific libraries of yeast artificial chromosome recombinants from somatic hybrid cell lines. Methods Mol Biol 29: 379-402, 1994.

14 Hochgeschwender U, Sutcliffe JG and Brennan MB: Construction and screening of a genomic library specific for mouse chromosome 16. Proc Natl Acad Sci USA 86: 8482-8486, 1989.

15 Piontek K, Muller HW, Fischer U, Gottert E, Batzer MA, Meltzer PS, Trent JM and Meese E: Generation and characterization of a human chromosome 6-specific hncDNA library from a somatic cell hybrid. Cytogenet Cell Genet 69: 273-278, 1995. 
16 Okada Y: Analysis of giant polynuclear cell formation caused by HVJ virus from Ehrlich's ascites tumor cells. I. Microscopic observation of giant polynuclear cell formation. Exp Cell Res 26: 98-107, 1962 .

17 Harris H and Watkins JF: Hybrid cells derived from mouse and man: artificial heterokaryons of mammalian cells from different species. Nature 205: 640-646, 1965.

18 Weiss MC, Green H: Human-mouse hybrid cell lines containing partial complements of human chromosomes and functioning human genes. Proc Natl Acad Sci USA 58: 1104-1111, 1967.

19 Boone C, Chen TR and Ruddle FH: Assignment of three human genes to chromosomes (LDH-A to 11 , TK to 17 , and IDH to 20) and evidence for translocation between human and mouse chromosomes in somatic cell hybrids (thymidine kinaselactate dehydrogenase A-isocitrate dehydrogenase-C-11, E-17, and F-20 chromosomes). Proc Natl Acad Sci USA 69: 510-514, 1972.

20 Mirsky AE, Burdick CJ, Davidson EH and Littau, VC: The role of lysine-rich histone in the maintenance of chromatin structure in metaphase chromosomes. Proc Natl Acad Sci USA 61: 592597,1968

$21 \mathrm{McBride}$ OW and Ozer HL: Transfer of genetic information by purified metaphase chromosomes. Proc Natl Acad Sci USA 70: 1258-1262, 1973

22 Bakay B, Croce CM, Koprowski H and Nyhan W: Restoration of hypoxanthine phosphoribosyl transferase activity in mouse $1 \mathrm{R}$ cells after fusion with chick-embryo fibroblasts. Proc Natl Acad Sci USA 70: 1998-2002, 1973.

23 Burch JW and McBride OW: Human gene expression in rodent cells after uptake of isolated metaphase chromosomes. Proc Natl Acad Sci USA 72: 1797-1801, 1975.

24 Willecke $\mathrm{K}$ and Ruddle FH: Transfer of the human gene for hypoxanthine guanine phosphoribosyltransferase via isolated human metaphase chromosomes into mouse L-cells. Proc Natl Acad Sci USA 72: 1792-1796, 1975.

25 McBride OW and Peterson JL: Chromosome-mediated gene transfer in mammalian cells. Annu Rev Genet 14: 321-345, 1980.

26 Spandidos DA and Siminovitch L: Transfer of codominant markers by isolated metaphase chromosomes in Chinese hamster ovary cells. Proc Natl Acad Sci USA 74: 3480-3484, 1977.

27 Miller CL and Ruddle FH: Co-transfer of human X-linked markers into murine somatic cells via isolated metaphase chromosomes. Proc Natl Acad Sci USA 75: 3346-3350, 1978.

28 Athwal RS and McBride OW: (1977). Serial transfer of a human gene to rodent cells by sequential chromosome-mediated gene transfer. Proc Natl Acad Sci USA 74: 2943-2947, 1977.

29 McBride OW, Burch JW and Ruddle FH: Cotransfer of thymidine kinase and galactokinase genes by chromosomemediated gene transfer. Proc Natl Acad Sci USA 75: 914-918, 1978.

30 Tischfield JA and Ruddle FH: Assignment of the gene for adenine phosphoribosyltransferase to human chromosome 16 by mouse-human somatic cell hybridization. Proc Natl Acad Sci USA 71: 45-49, 1974.

31 Wigler M, Pellicer A, Silverstein S, Axel R, Urlaub G and Chasin L: DNA-mediated transfer of the adenine phosphoribosyltransferase locus into mammalian cells. Proc Natl Acad Sci USA 76: 1373-1376, 1979.

32 Mulligan RC and Berg P: Expression of a bacterial gene in mammalian cells. Science 209: 1422-27, 1980.
33 Ruddle F, Chapman VM, Ricciuti F, Murnane M, Klebe R and Meera Khan P: Linkage relationships of seventeen human gene loci as determined by man - mouse somatic cell hybrids. Nat New Biol 232: 69-73, 1971.

34 Croce CM, Bakay B, Nyhan WL and Koprowski H: Reexpression of the rat hypoxanthine phosphoribosyltransferase gene in rat-human hybrids. Proc Natl Acad Sci USA 70: 25902594, 1973.

35 Miller OJ, Allderdice PW, Miller DA, Breg WR and Migeon BR: Human thymidine kinase gene locus: assignment to chromosome 17 in a hybrid of man and mouse cells. Science 173: 244-245, 1971.

36 Fournier RE and Ruddle FH: Microcell-mediated transfer of murine chromosomes into mouse, Chinese hamster, and human somatic cells. Proc Natl Acad Sci USA 74: 319-323, 1977.

37 Fournier RE and Frelinger JA: Construction of microcell hybrid clones containing specific mouse chromosomes: application to autosomes 8 and 17. Mol Cell Biol 2: 526-534, 1982.

38 Dhar V, Searle BM and Athwal RS: Transfer of Chinese hamster chromosome 1 to mouse cells and regional assignment of 7 genes: A combination of gene transfer and microcell fusion. Somatic Cell Mol Genet 10: 547-559, 1984.

39 Friend KK, Chen S and Ruddle FH: Differential staining of interspecific chromosomes in somatic cell hybrids by alkaline Giemsa stain. Somatic Cell Genet 2: 183-188, 1976.

40 Athwal RS, Smarsh M, Searle BM and Deo SS: Integration of a dominant selectable marker into human chromosomes and transfer of marked chromosomes to mouse cells by microcell fusion. Somatic Cell Mol Genet 11: 177-188, 1985.

41 Ning Y, Lovell M, Cooley LD and Pereira-Smith O: PCR karyotype of monochromosomal somatic cell hybrids. Genomics 16: 758-760, 1993.

42 Inoue J, Mitsuya K, Maegawa S, Kugoh H, Kadota M, Okamura D, Shinohara T, Nishihara S, Takehara S, Yamauchi K, Schulz TC and Oshimura, M: Construction of 700 human/mouse A9 monochromosomal hybrids and analysis of imprinted genes on human chromosome 6. J Hum Genet 46: 137-145, 2001

43 Creagan RP and Ruddle FH: The clone panel: a systematic approach to gene mapping using interspecific somatic cell hybrids. Cytogenet Cell Genet 14: 282-286, 1975.

44 Patel PI, Garcia C, Montes de Oca-Luna R, Malamut RI, Franco, B, Slaugenhaupt S, Chakravarti A and Lupski JR: Isolation of a marker linked to the Charcot-Marie-Tooth disease type IA gene by differential Alu-PCR of human chromosome 17-retaining hybrids. Am J Hum Genet 47: 926-934, 1990.

45 Wasmuth JJ, Carlock LR, Smith B and Immken LL: A cell hybrid and recombinant DNA library that facilitate identification of polymorphic loci in the vicinity of the Huntington disease gene. Am J Hum Genet 39: 397-403, 1986.

46 Cuthbert AP, Trott DA, Ekong RM, Jezzard S, England NL, Themis M, Todd CM and Newbold RF: Construction and characterization of a highly stable human: rodent monochromo-somal hybrid panel for genetic complementation and genome mapping studies. Cytogenet Cell Genet 71(1): 6876, 1995.

47 Sandhu AK, Hubbard K, Kaur GP, Jha KK, Ozer HL and Athwal RS: Senescence of immortal human fibroblasts by the introduction of normal human chromosome 6. Proc Natl Acad Sci USA 91: 5498-5502, 1994. 
48 Sandhu AK, Kaur GP, Reddy DE, Rane NS and Athwal RS: A gene on 6q 14-21 restores senescence to immortal ovarian tumor cells. Oncogene 12: 247-252, 1996.

49 Rane NS, Sandhu AK, Zhawar,VS, Kaur G, Popescu NC and Kandpal RP, Jhanwar-Uniyal M, Athwal RS: Restoration of senescence in breast and ovarian cancer cells following the transfer of the YAC carrying SEN6A gene located at 6q16.3. Cancer Genomics Proteomics 8: 227-233, 2011.

50 Banga SS, Kim S, Hubbard K, Dasgupta T, Jha KK, Patsalis P, Hauptschein R, Gamberi B, Dalla-Favera R, Kraemer P and Ozer HL: SEN6, a locus for SV40-mediated immortalization of human cells, maps to 6q26-27. Oncogene 14: 313-321, 1997.

51 Reddy DE, Sandhu AK, Deriel JK, Athwal RS and Kaur GP: Identification of a gene at $16 \mathrm{q} 24.3$ that restores cellular senescence in immortal mammary tumor cells. Oncogene 18 : 5100-5107, 1999.

52 Liu J, Zhawar VK, Kaur G, Kaur GP, Deriel JK, Kandpal RP and Athwal RS: Chromosome 6 encoded RNaseT2 protein is a cell growth regulator. J Cell Mol Med 14: 1146-1155, 2010.

53 Acquati F, Morelli C, Cinquetti R, Bianchi MG, Porrini D, Varesco L, Gismondi V, Rocchetti R, Talevi S, Possati L, Magnanini C, Tibiletti MG, Bernasconi B, Daidone MG, Shridhar V, Smith DI, Negrini M, Barbanti-Brodano G and Taramelli R: Cloning and characterization of a senescence inducing and class II tumor suppressor gene in ovarian carcinoma at chromosome region 6q27. Oncogene 20: 980-988, 2001.

54 Zhawar VK, Kaur G, deRiel JK, Kaur GP, Kandpal RP and Athwal RS: Novel spliced variants of ionotropic glutamate receptor GluR6 in normal human fibroblast and brain cells are transcribed by tissue specific promoters. Gene 459: 1-10, 2010.

55 Lefter LP, Furukawa T, Sunamura M, Duda DG, Takeda K, Kotobuki N, Oshimura M, Matsuno S and Horii A: Suppression of the tumorigenic phenotype by chromosome 18 transfer into pancreatic cancer cell lines. Genes Chromosomes Cancer 34 234-242, 2002.

56 Murakami YS, Brothman AR, Leac, RJ, White RL: Suppression of malignant phenotype in a human prostate cancer cell line by fragments of normal chromosomal region 17q. Cancer Res 55: 3389-3394, 1995.

57 Bleuel K, Popp S, Fusenig NE, Stanbridge EJ, Boukamp P: Tumor suppression in human skin carcinoma cells by chromosome 15 transfer or thrombospondin-1 overexpression through halted tumor vascularization. Proc Natl Acad Sci USA 96: 2065-2070, 1999.

58 Kost-Alimova M, Fedorova L, Yang Y, Klein G and Imreh S: Microcell-mediated chromosome transfer provides evidence that polysomy promotes structural instability in tumor cell chromosomes through asynchronous replication and breakage within latereplicating regions. Genes Chromosomes Cancer 40: 316-324, 2004.

59 Kaur GP and Athwal RS: Complementation of a DNA repair defect in xeroderma pigmentosum by transfer of human chromosome 9. Proc Natl Acad Sci USA 86: 8872-8876, 1989.

60 Schultz RA, Saxon PJ, Glover TW and Friedberg EC: Microcellmediated transfer of a single human chromosome complements xeroderma pigmentosum group A fibroblasts. Proc Natl Acad Sci USA 84: 4176-4179, 1987.

61 Flejter WL, McDaniel LD, Johns D, Friedberg EC and Schultz RA: Correction of xeroderma pigmentosum complementation group D mutant cell phenotypes by chromosome and gene transfer: involvement of the human ERCC2 DNA repair gene. Proc Natl Acad Sci USA 89: 261-265, 1992.
62 Kaur GP and Athwal RS: Complementation of DNA repair defect in XP-C by transfer of human chromosome 5. Somatic Cell Molecular Genet 19: 83-93, 1993.

63 Jeggo PA, Hafezparast M, Thompson AF, Kaur GP, Zdzienicka $\mathrm{MZ}$ and Athwal RS: Localization of a DNA repair gene (XRCC5) involved in double-strand-break rejoining to human chromosome 2. Proc Natl Acad Sci USA 89: 6423-6427, 1992.

64 Kaur GP and Athwal RS: Genetic analysis of DNA repair defects in XP cells: Identification of complementing genes. In: Mechanisms of environmental mutagenesis-carcinogenesis. Kappas A (eds.). Springer US, pp. 151-159, 1990.

65 Banga SS, Hall KT, Sandhu AK, Weaver DT and Athwal RS: Complementation of $\mathrm{V}(\mathrm{D}) \mathrm{J}$ recombination defect and X-ray sensitivity of scid mouse cells by human chromosome 8 . Mutation Res 315: 239-247, 1994.

66 Digiovanna JJ and Kraemer KH: Shining a light on xeroderma pigmentosum. J Investigative Dermatol 132: 785-796, 2012.

67 Athwal RS and Sandhu SS: Use of a human X mouse hybrid cell line to detect aneuploidy. Mutation Res 149: 73-81, 1985.

68 Sandhu S., Gudi RD and Athwal RS: A monochromosomal hybrid cell assay for evaluating genotoxicity of environmental chemicals. Cell Biol Toxicol 4: 495-506, 1988.

69 Brown DM, Chan YA, Desai PJ, Grzesik P, Oldfield LM, Vashee S, Way JC, Silver PA and Glass JI: Efficient size-independent chromosome delivery from yeast to cultured cell lines. Nucleic Acids Res pii: gkw1252, 2016. [Epub ahead of print].

70 Liskovykh M, Lee NC, Larionov V and Kouprina N: Moving toward a higher efficiency of microcell-mediated chromosome transfer. Mol Ther Methods Clin Dev 3: 16043, 2016.

71 Suzuki T, Kazuki Y, Oshimura M and Hara T: Highly efficient transfer of chromosomes to a broad range of target cells using Chinese hamster ovary cells expressing murine leukemia virusderived envelope proteins. PLoS One 11: e0157187, 2016.

72 Hiratsuka M, Ueda K, Uno N, Uno K, Fukuhara S, Kurosaki H, Takehara S, Osaki M, Kazuki Y, Kurosawa Y, Nakamura T, Katoh $\mathrm{M}$ and Oshimura M: Retargeting of microcell fusion towards recipient cell-oriented transfer of human artificial chromosome. BMC Biotechnol 15: 58, 2015.

73 Oshimura M, Uno N, Kazuki Y, Katoh M, Inoue T: A pathway from chromosome transfer to engineering resulting in human and mouse artificial chromosomes for a variety of applications to bio-medical challenges. Chromosome Res 23: 111-133, 2015.

74 Meguro-Horike M and Horike S: MMCT-mediated chromosome engineering technique applicable to functional analysis of lncRNA and nuclear dynamics. Methods Mol Biol 1262: 277289, 2015.

75 Kandpal R, Saviola B and Felton J: The era of 'omics unlimited. Biotechniques 46: 351-352, 354-355, 2009.

76 Rodier F and Campisi J: Four faces of cellular senescence. J Cell Biol 192: 547-556, 2011.

77 Grivennikov SI, Greten FR and Karin M: Immunity, inflammation, and cancer. Cell 140: 883-899, 2010.

Received January 9, 2017

Revised February 19, 2017

Accepted February 22, 2017 